\title{
Kaolin and salicylic acid foliar application modulate yield, quality and phytochemical composition of olive pulp and oil from rainfed trees
}

\author{
Cátia Brito ${ }^{\mathrm{a}}$, Lia-Tânia Dinis ${ }^{\mathrm{a}}$, Ermelinda Silva ${ }^{\mathrm{a}}$, Alexandre Gonçalves ${ }^{\mathrm{a}}$, Carlos Matos ${ }^{\mathrm{b}}$, \\ Manuel A. Rodrigues ${ }^{\mathrm{c}}$, José Moutinho-Pereira ${ }^{\mathrm{a}}$, Ana Barros ${ }^{\mathrm{a}}$, Carlos Correia ${ }^{\mathrm{a}, *}$ \\ ${ }^{\text {a } C I T A B}$ - Centre for the Research and Technology of Agro-Environmental and Biological Sciences, Universidade de Trás-os-Montes e Alto Douro, 5000-801, Vila Real, \\ Portugal

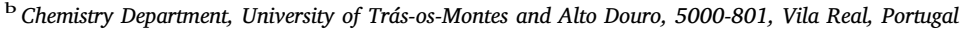

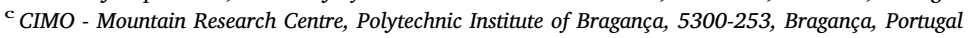

\section{A R T I C L E I N F O}

\section{Keywords:}

Olive tree

Summer stress

Frosts

Phytochemicals

Antioxidant capacity

\begin{abstract}
A B S T R A C T
Olive orchards, rainfed managed, are threatened by the current and predicted adverse environmental conditions, which change the yield and quality of olive products, largely known for its benefits to human health. To mitigate these problems, it is highly recommended to perform some adjustments in agronomic practices, such as the use of foliar sprays that cloud help the trees to cope with climate change. During two consecutive years, olive trees were pre-harvest sprayed with kaolin (KL) and salicylic acid (SA) to attenuate the adverse effects of summer stress. Olive yield was increased by $97 \%$ and $72 \%$ with KL and SA, respectively. Phenolics and antioxidant capacity of both olives and olive oil increased and decreased in the first and second year, respectively, in a closely association with the prevailing climatic conditions. The foliar sprays did not significantly affect the oil quality indices, free acidity, peroxide value and $\mathrm{K}_{232}$ coefficient and decreased the $\mathrm{K}_{270}$ coefficient. This study strongly suggests that the applied products might be effective in mitigating the adverse environmental conditions, without substantial changes in fruit and olive oil quality.
\end{abstract}

\section{Introduction}

Olive tree (Olea europaea L.) is one of the oldest and emblematic cash crops of the Mediterranean Basin, being cultivated mostly under rainfed production systems. Although the species can tolerate harsh conditions, the sector is under threat by the current adverse environmental circumstances and even more by the future scenarios of climate change (IPCC, 2013). Agricultural yield losses due to environmental stresses are well documented and many studies have shown that is crucial to increase the efforts in adapting measures to help the plants to cope with such adverse conditions (Wang and Frei, 2011). The limited water resources associated with the rugged topography of traditional olive growing areas hinders the implementation of irrigation systems, and/or make it economically unsustainable. Alternatively, the exogenous application of kaolin (KL) and salicylic acid (SA) can be adequate short-term solutions to attenuate the adverse effects of summer associated stresses. KL is a white mineral clay that avoid the accumulation of heat load through the reflection of sunlight, reducing the risk of leaf and fruit damage from high temperatures and solar injury (Glenn and Puterka, 2004) and SA is a signaling phytohormone with diverse regulatory roles in plant metabolism and abiotic stress tolerance (Khan et al., 2015). However, the influence of these substances on crop quality have received less attention than the influence on yield, possibly because they are more difficult to detect and sometimes are not consensual. The application of SA increased the yield of olive (Abd ElRazek et al., 2013; Khalil et al., 2012), peach (El-Shazly et al., 2013) and strawberry (Jamali et al., 2011; Kazemi, 2013) crops. In peach trees, the fruit quality was negatively affected, with lower soluble solids and anthocyanins accumulation and higher acidity (El-Shazly et al., 2013), whereas the quality of strawberry fruits was improved, with higher accumulation of total phenols, both flavonoids and non-flavonoids, soluble solids and vitamin C (Kazemi, 2013). With KL application, an increase in yield of olive (Saour and Makee, 2003), grapevine (Correia et al., 2014), mango (Chamchaiyaporn et al., 2013) and apple (Glenn et al., 2003) crops was reported. In olive trees, KL affected positively the olive oil quality and composition, in terms of total phenols,

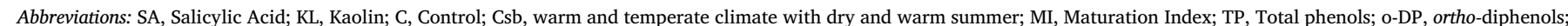

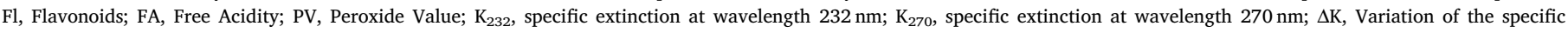
extinction

* Corresponding author.

E-mail address: ccorreia@utad.pt (C. Correia). 
pigments, oil content, fatty acids, free acidity, peroxide value and ultraviolet (UV) absorption coefficients (Khaleghi et al., 2015; Saour and Makee, 2003). In grapevines, KL contributed to the increase of secondary metabolites in fruits, as total phenols, flavonoids, anthocyanins and vitamin C, as well as antioxidant capacity (Dinis et al., 2016).

The beneficial effects of olives and olive oil in health can be attributed to the antioxidant properties associated to the phenolic composition (Ghanbari et al., 2012; Silva et al., 2006; Sousa et al., 2014a). Phenolic compounds in olives comprise 1-3\% of the fresh pulp weight, standing out the phenolic acids, phenolic alcohols, flavonoids, and the secoiridoids, which include the predominant phenolic compound found in fresh olive, oleuropein (Charoenprasert and Mitchell, 2012; Silva et al., 2006). In extra virgin olive oil, the concentration of phenols varies from 50 to $800 \mathrm{mg} \mathrm{kg}^{-1}$ oil (Charoenprasert and Mitchell, 2012). Reactive oxygen species (ROS), formed as a result of oxidative stress, are known to be responsible for the development of some diseases, targeting lipids, proteins and deoxyribonucleic acid (DNA) in living organisms (Ghanbari et al., 2012). Phenolic compounds in olives can restrict the deleterious effects of ROS, either by their free radical scavenging ability (by donating a hydrogen atom to the ROS, reducing and stabilizing it), or by chelating transition metals, suppressing the oxidative reaction in which them are involved (Charoenprasert and Mitchell, 2012). These phytochemicals also affect the sensorial and aromatic characteristics of both olive fruits and oil and the chemical stability of olive oil (Ghanbari et al., 2012; Servili et al., 2009). However, the composition and concentration of phenolic compounds is the result of a complex interaction of various pre-harvest factors, such as cultivars, environmental conditions, ripening stage and agronomic practices (Barros et al., 2013; Brahmi et al., 2013; Damak et al., 2008; Dinis et al., 2016; Ghanbari et al., 2012; Gómez-Rico et al., 2006; Jemai et al., 2009; Kazemi, 2013; Machado et al., 2013; Silva et al., 2006; Soufi et al., 2014; Sousa et al., 2014a, 2015; Sousa et al., 2014b; Talhaoui et al., 2015, 2016; Vinha et al., 2005).

We hypothesized that foliar sprays KL and SA might improve the olive trees yield without substantial changes in olives and olive oil quality. Hence, the aim of this work was to assess the influence of KL and SA in yield and in olive fruits and oil phenolics concentration and antioxidant capacity, as well in oil quality indices. The effects of harvest date and differences among years on those variables were also considered.

\section{Material and methods}

\subsection{Field trial and sampling}

The experiment took place in Bragança, Portugal, at Pinheiro Manso farm $\left(41^{\circ} 48^{\prime} \mathrm{N}, 6^{\circ} 44^{\prime} \mathrm{W}\right)$, during two consecutive growing seasons (2015 and 2016), on a 5-years-old rainfed olive orchard (cv. "Cobrançosa") planted at $7 \times 6 \mathrm{~m}$. The climate is of Mediterranean type with some Atlantic influence. Under the Koppen-Geiger climate classification, Bragança had a warm and temperate climate with dry and warm summer (Csb) and rainy winters (IPMA, 2017). The average air temperature and monthly precipitation recorded during the experimental period are shown in Fig. 1. Selected physico-chemical characteristics of the olive grove soil $(0-20 \mathrm{~cm}$ depth) at the beginning of the experiment are presented in Table 1 . After drying $\left(40{ }^{\circ} \mathrm{C}\right)$ and sieving ( $2 \mathrm{~mm}$ mesh), soil samples were subjected to several analytical determinations: 1) clay, silt and sand, by the Robinson pipette method; 2) $\mathrm{pH}\left(\mathrm{H}_{2} \mathrm{O}, \mathrm{KCl}\right)$; 3) organic carbon (C), determined by the WalkleyBlack method (easily oxidizable $\mathrm{C}$ ), and by incineration (total organic C); 4) extractable B by the hot water extraction method and determined by azometine- $\mathrm{H}$ colorimetric procedure; 5 ) extractable $\mathrm{P}$ and $\mathrm{K}$, by using ammonium lactate solution at $\mathrm{pH} 3.7 ; 6$ ) exchangeable bases $\left(\mathrm{Ca}^{2+}, \mathrm{Mg}^{2+}, \mathrm{K}^{+}\right.$and $\left.\mathrm{Na}^{+}\right)$, determined by ammonium acetate, $\mathrm{pH} 7.0$; and 7) exchangeable acidity extracted by $1 M \mathrm{KCl}$. Methods 1-3 and 6-7 are fully described in Van Reeuwijk (2002), 4 in Keren, 1996 and 5 in
Houba et al. (1997).

The experiment comprises three treatments: control (C) trees, sprayed with distilled water; kaolin (KL) trees, sprayed with an aqueous solution of kaolin (Surround ${ }^{\circledR}$ WP, Engelhard Corporation, Iselin, NJ), at the manufacturer recommended dosage $5 \%(\mathrm{w} / \mathrm{v})$; and salicylic acid (SA) trees, sprayed with an aqueous solution of $100 \mu \mathrm{M} \mathrm{SA}$, selected based on results of preliminary research. The treatments were made in the absence of wind in the morning of 30th June 2015 and 23th June 2016. A second application in the same days was done for KL trees, in order to ensure the adhesion uniformity of kaolin clay particles. The kaolin treatment was repeated in 27th August 2016 after a heavy rain event. All spray applications were supplemented with $0.1 \%(\mathrm{v} / \mathrm{v})$ Tween 20 and conducted according to good efficacy practice standard operating procedures adjusted for agricultural experiments. Each treatment included three replicates, completely randomized, with three trees of similar canopy size per plot. Each treatment was separated by a buffer line of trees and all trees were managed without irrigation and cared with the same fertilization, pruning, weed control and pest management practices, as applied by local commercial farmers.

Olive fruits were handpicked from the selected olive trees. In 2015 two harvests were performed in order to evaluate the maturation index and the evolution of the chemical composition of fruits, from an earlier harvest (9th November) (H1 2015) to the traditional harvest for olive oil extraction at the study site (30th November) (H2 2015). In 2016 only the last sampling (9th December) (H1 2016) was performed. Additionally, in both years, the overall production per tree was evaluated. In the H2 2015 and H1 2016 were also collected fruits for olive oil extraction.

\subsection{Maturation index}

The maturation index (MI) was determined according to the method proposed by Hermoso et al. (1991) and varied between 0 and 7. Olive fruits were classified into the following categories: 0 - olives with intense green epidermis; 1 - olives with yellowish green epidermis; 2 olives with red spots or areas in less than half of the fruit; 3 - olives with red or light violet epidermis over more than half of the fruit; 4 - olives with black epidermis and totally white pulp; 5 - olives with black epidermis and less than half purple pulp; 6 - olives with black epidermis and more than half purple pulp; 7 - olives with black epidermis and totally purple pulp. With a to $h$ being the number of fruits in each category, the MI was calculated as follows:

$M I=$

$(a \times 0+b \times 1+c \times 2+d \times 3+e \times 4+f \times 5+g \times 6+\mathrm{h} \times 7) /$ 100

\subsection{Olive oil extraction}

Olive oil extraction was extracted within $24 \mathrm{~h}$ of the olive harvest. A bench hammer mill that reproduces industrial oil extraction was used for the extraction of olive oil from two kg of healthy fruits, without any kind of infection or physical damage. Then, the paste was slowly malaxed at about $25^{\circ} \mathrm{C}$ for $40 \mathrm{~min}$, centrifuged in a two-phase decanter at $3500 \times$ for $10 \mathrm{~min}$, and the oil collected was placed in dark glass bottles and kept at $4{ }^{\circ} \mathrm{C}$ for latter analysis.

\subsection{Extraction of polyphenolic compounds from olive fruits and olive oil}

The fruits and olive oil extraction was adapted from a procedure described by Sousa et al. (2014b). Freeze-dried olive pulp (300 mg) was grind and homogenized with $6 \mathrm{ml}$ of $\mathrm{MeOH} / \mathrm{H}_{2} \mathrm{O}(70: 30, \mathrm{v} / \mathrm{v})$ for $30 \mathrm{~min}$ at room temperature. Then, the samples were centrifuged at $2800 \mathrm{~g}$ for $10 \mathrm{~min}$ and the supernatant was removed and reserved in a flask after filtration. This procedure was repeated three times. To 


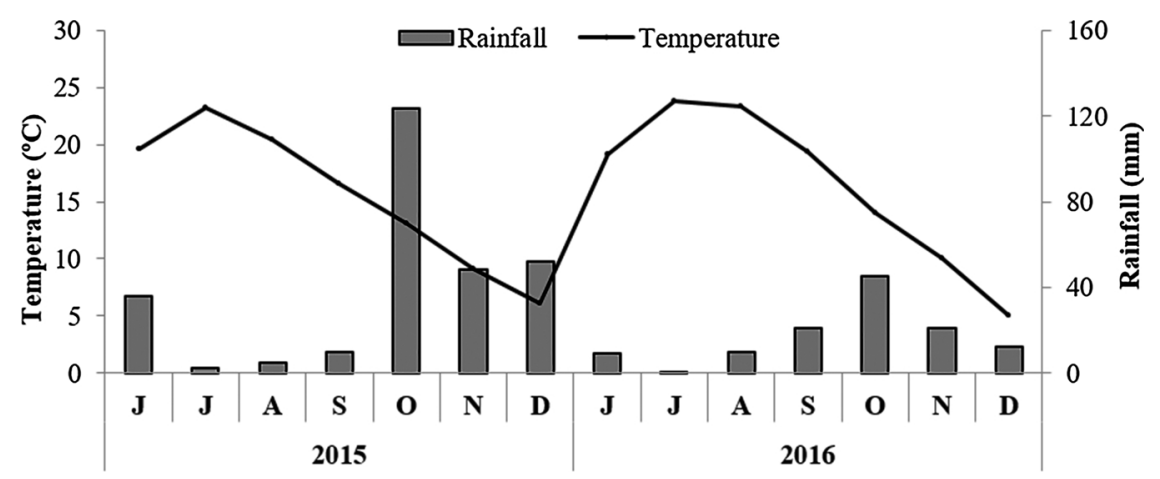

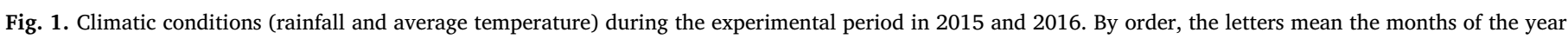
monitored: June (J), July (J), August (A), September (S), October (O), November (N) and December (D).

Table 1

Selected properties of the soil used in the field experiment sampled shortly before the trial started at a depth of $0-20 \mathrm{~cm}$.

\begin{tabular}{|c|c|c|c|}
\hline Soil properties & & Soil properties & \\
\hline Clay (\%) & 14.5 & Extractable $\mathrm{P}\left(\mathrm{mg} \mathrm{P}_{2} \mathrm{O}_{5} \mathrm{~kg}^{-1}\right)^{\mathrm{d}}$ & 87.9 \\
\hline Silt (\%) & 27.7 & Extractable $\mathrm{K}\left(\mathrm{mg} \mathrm{K}_{2} \mathrm{O} \mathrm{kg}^{-1}\right)^{\mathrm{d}}$ & 102.0 \\
\hline Sand (\%) & 57.8 & Exchangeable bases $^{\mathrm{e}}$ & \\
\hline $\mathrm{pH}_{\mathrm{H} 2 \mathrm{O}}$ & 5.8 & $\mathrm{Ca}\left(\mathrm{cmol}_{\mathrm{c}} \mathrm{kg}^{-1}\right)$ & 7.2 \\
\hline $\mathrm{pH}_{\mathrm{KCl}}$ & 4.6 & $\mathrm{Mg}\left(\mathrm{cmol}_{\mathrm{c}} \mathrm{kg}^{-1}\right)$ & 2.2 \\
\hline Oxidizable $\mathrm{C}\left(\mathrm{g} \mathrm{kg}^{-1}\right)^{\mathrm{a}}$ & 8.5 & $\mathrm{~K}\left(\mathrm{cmol}_{\mathrm{c}} \mathrm{kg}^{-1}\right)$ & 0.2 \\
\hline Total organic $\mathrm{C}\left(\mathrm{g} \mathrm{kg}^{-1}\right)^{\mathrm{b}}$ & 25.6 & $\mathrm{Na}\left(\mathrm{cmol}_{\mathrm{c}} \mathrm{kg}^{-1}\right)$ & 0.4 \\
\hline Extractable B $\left(\mathrm{mg} \mathrm{kg}^{-1}\right)^{\mathrm{c}}$ & 0.5 & Exchangeable acidity $\left(\mathrm{cmol}_{\mathrm{c}} \mathrm{kg}^{-1}\right)$ & 0.5 \\
\hline
\end{tabular}

a Walkley-Black.

$\mathrm{b}$ Incineration.

c Azomethine $\mathrm{H}$.

d Ammonium-lactate.

e Ammonium-acetate, $\mathrm{pH} 7$.

remove the fat phase, the mixture was washed tree times with $6 \mathrm{~mL}$ of hexane and the organic phase was discarded. Extractions were performed in triplicate. Each extract was introduced into a $25 \mathrm{~mL}$ round bottom flask, which was filled up to the mark with $\mathrm{MeOH} / \mathrm{H}_{2} \mathrm{O}$ (70:30, v/v).

Four $\mathrm{mL}$ of olive oil was weighed in a tube and followed by the addition of $2.5 \mathrm{~mL}$ of hexane and $2.5 \mathrm{~mL}$ of $\mathrm{MeOH} / \mathrm{H}_{2} \mathrm{O}(70: 30, \mathrm{v} / \mathrm{v})$. Then, the samples were centrifuged for $10 \mathrm{~min}$ at $2800 \mathrm{~g}$. The lower phase was carefully removed and reserved in a flask. This procedure was repeated three times. Extractions were performed in triplicate. Each extract was introduced into a $5 \mathrm{~mL}$ round bottom flask, which was filled up to the mark with $\mathrm{MeOH} / \mathrm{H}_{2} \mathrm{O}(70: 30$, v/v).

\subsection{Quantification of phenolic compounds}

\subsubsection{Total phenolic compounds}

The concentration of total phenolic compounds (TP) in methanolic extracts was determined using a Folin-Ciocalteu reagent according to the described by Barros et al. (2013) with some adaptations to microplates, using gallic acid as standard. This method is based on the reduction of a phosphowolframate-phosphomolybdate complex by phenolics to blue reaction products. To $20 \mu \mathrm{L}$ of properly diluted methanolic extracts was added $100 \mu \mathrm{L}$ of the Folin-Ciocalteu reagent and $80 \mu \mathrm{l}$ of $7.5 \%$ sodium carbonate solution. After $30 \mathrm{~min}$ of incubation at $40-45^{\circ} \mathrm{C}$ the absorbance of both standard and samples, was measured at $750 \mathrm{~nm}$. All measurements were performed in triplicate. The results were expressed as milligrams of gallic acid equivalents per gram of olive flesh (dry weight) (mg GAE $\mathrm{g}^{-1}$ ) or kilogram of olive oil (mg GAE kg-1).

\subsubsection{Flavonoids}

The concentration of flavonoids ( $\mathrm{Fl}$ ) was determined following the method proposed by Zhishen et al. (1999) with adaptations to microplates, using catechin as a standard. To $24 \mu \mathrm{L}$ of properly diluted methanolic extracts was added $28 \mu \mathrm{L} \mathrm{NaNO}_{2} 5 \%$. After $5 \mathrm{~min}$ in the dark, was added $28 \mu \mathrm{L}$ of $\mathrm{AlCl}_{3} 10 \%$ and after $6 \mathrm{~min}$ in the dark, $120 \mu \mathrm{L}$ of $1 \mathrm{M}$ $\mathrm{NaOH}$ was added. The mixture was shaken and the absorbance of the standard and samples was measured at $510 \mathrm{~nm}$. All measurements were performed in triplicate. The results were expressed as milligrams of catechin equivalents per gram of olive flesh (dry weight) $\left(\mathrm{mg} \mathrm{CE} \mathrm{g}^{-1}\right)$ or kilogram of olive oil (mg $\mathrm{CE} \mathrm{kg}^{-1}$ ).

\subsubsection{Ortho-diphenols}

The concentration of ortho-diphenols (o-DP) was determined following the method proposed by Mateos et al. (2001) with adaptations to microplates, using gallic acid as a standard. To $160 \mu \mathrm{L}$ of properly diluted methanolic extracts was added $40 \mu \mathrm{L}$ of sodium molybdate $5 \%$ $(\mathrm{w} / \mathrm{v})$ in $50 \%$ methanol. After $15 \mathrm{~min}$ of incubation at room temperature the absorbance of the standard and samples was measured at $375 \mathrm{~nm}$. All measurements were performed in triplicate. The results were expressed as milligrams of gallic acid equivalents per gram of olive flesh (dry weight) (mg GAE $\mathrm{g}^{-1}$ ) or kilogram of olive oil (mg GAE $\left.\mathrm{kg}^{-1}\right)$.

\subsection{Quantification of the antioxidant capacity}

\subsubsection{ABTS $^{+}$radical scavenging assay}

The radical-scavenging activity determined by the 2,2-azino-bis(3ethylbenzothiazoline)-6 sulphonic acid (ABTS) radical cation decolorization assay was based on a method described by Ozgen et al. (2006) and Barros et al. (2011) with adaptations to microplates, using trolox as a standard. $\mathrm{ABTS}^{+}$radical was prepared by mixing an ABTS stock solution (7 mM in water) with $2.45 \mathrm{mM}$ potassium persulfate. This mixture was allowed to stand for $12-16 \mathrm{~h}$ at room temperature in the dark until reaching a stable oxidative state. The ABTS solution was diluted with $20 \mathrm{mM}$ sodium acetate buffer $(\mathrm{pH} 4.5)$ to an absorbance of $0.70 \pm 0.02$ at $734 \mathrm{~nm}$. To a $12 \mu \mathrm{l}$ of properly diluted methanolic extracts was added $188 \mu \mathrm{L}$ of $\mathrm{ABTS}^{+}$solution. After $30 \mathrm{~min}$ of incubation in dark at room temperature the absorbance of the standard and samples was measured at $734 \mathrm{~nm}$. All measurements were performed in triplicate. The antioxidant activity of the extract was calculated as Trolox Equivalent Antioxidant Capacity (TEAC) and was expressed as mmol of Trolox equivalents per $\mathrm{kg}$ of olive flesh (dry weight) and oil (mmol TEAC kg ${ }^{-1}$ ). A standard curve of the percentage of $\mathrm{ABTS}^{+}$inhibition in function of Trolox concentration was used for the calculations.

\subsubsection{DPPH radical scavenging assay}

$\mathrm{DPPH} \cdot$ radical scavenging assay was carried out as previously 
reported by Domínguez-Perles et al. (2014) with some modifications, using trolox as a standard. For this assay, it was prepared a solution of $8.87 \mathrm{mM}$ of DPPH and diluted in methanol/ $\mathrm{H}_{2} \mathrm{O}(70: 30, v / v)$ to achieve an absorbance closer to 1.000 at $520 \mathrm{~nm}$. To $10 \mu \mathrm{L}$ of properly diluted methanolic extracts was added $190 \mu \mathrm{L}$ of DPPH solution. After $30 \mathrm{~min}$ of incubation in dark at room temperature the absorbance of the standard and samples was measured at $520 \mathrm{~nm}$. All measurements were performed in triplicate. The antioxidant activity of the extract was calculated as Trolox Equivalent Antioxidant Capacity (TEAC) and was expressed as mmol of Trolox equivalents per kg of olive flesh (dry weight) and oil (mmol TEAC $\mathrm{kg}^{-1}$ ). A standard curve of the percentage of $\mathrm{DPPH}^{+}$inhibition in function of Trolox concentration was used for the calculations

\subsubsection{Ferric reducing antioxidant power}

The ferric reducing antioxidant power (FRAP) was performed according to Bolanos de la Torre et al. (2015) with minor alterations, using trolox as a standard. The FRAP working solution was prepared daily by mixing 10 volumes of acetate buffer $(300 \mathrm{mM}, \mathrm{pH} 3.6)$ with 1 volume of 2, 4, 6-tris(2-pyridyl)-S-triazine (TPTZ) (10 mM dissolved with $40 \mathrm{mM} \mathrm{HCl})$ and 1 volume of ferric chloride $\left(\mathrm{FeCl}_{3}\right)(20 \mathrm{mM}$ in water). The solution was warmed at $37^{\circ} \mathrm{C}$ for $10 \mathrm{~min}$ before use. To $20 \mu \mathrm{l}$ of properly diluted methanolic extracts was added $280 \mu \mathrm{L}$ of FRAP working solution. After $30 \mathrm{~min}$ of incubation in dark at $37^{\circ} \mathrm{C}$ the absorbance of the standard and samples was measured at $593 \mathrm{~nm}$. All measurements were performed in triplicate. The antioxidant activity of the extract was calculated as Trolox Equivalent Antioxidant Capacity (TEAC) and was expressed as mmol of Trolox equivalents per $\mathrm{kg}$ of olive flesh (dry weight) and oil (mmol TEAC $\mathrm{kg}^{-1}$ ). A standard curve of the reading absorbance in function of Trolox concentration was used for the calculations.

\subsection{Determination of oil quality parameters}

The oil quality parameters were determined according to the European Community regulation EEC/2568/91(Regulation, 1991). Free acidity (FA) measures the hydrolytic breakdown of triglycerides to mono and di-glycerides, leading to fatty acid liberation. This variable is an indicator of the olives quality, the procedures of harvesting, handling, transportation and storage prior to olive milling (Khaleghi et al., 2015). FA was expressed as \% oleic acid per $100 \mathrm{~g}$ oil. Peroxide value (PV) is a measure of the active oxygen bound by the oil, which reflects the hydroxyperoxide value (Khaleghi et al., 2015). PV was expressed as mgEqO$~_{2} \mathrm{~kg}^{-1}$ oil. The ultraviolet spectrophotometric analysis gives indications about the oxidation stage of the olive oil. The extinctions at specified wavelengths, $232 \mathrm{~nm}\left(\mathrm{~K}_{232}\right)$ and $270 \mathrm{~nm}\left(\mathrm{~K}_{270}\right)$, are related with the formation of conjugated diene and triene compounds, respectively, due to oxidation (Khaleghi et al., 2015). $\Delta \mathrm{K}$ is the variation of the specific extinction.

\subsection{Statistical analysis}

All statistical calculations were performed using the statistical software program SPSS for Windows (v. 22). After testing for ANOVA assumptions (homogeneity of variances with the Levene's mean test, and normality with the Kolmogorov-Smirnov test), statistical differences were evaluated by one-way analysis of variance (ANOVA)., followed by the post hoc Tukey's test ( $p$ values $<0.05)$. * - significant at $\mathrm{p}<0.05 ; * *$ - significant at $\mathrm{p}<0.01 ; * * *$ - significant at $\mathrm{p}<0.001$; n.s. - not significant at $\mathrm{p}>0.05$. The relationship between the concentration of phenolic compounds and the antioxidant activity in olive fruits and oil was analyzed by the Pearson correlation test and significance was set at $\mathrm{p}<0.05$.

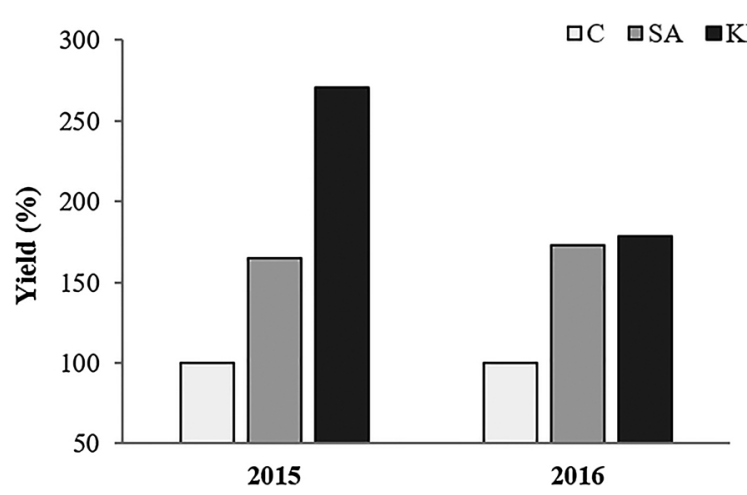

Fig. 2. Influence of control (C), salicylic acid (SA) and kaolin (KL) treatments on yield in the two years of experiment (the values mean relative change against the minimum value, set out $100 \%)(n=9)$.

\section{Results}

\subsection{Yield and ripening degree of fruits}

Fig. 2 shows that both applied substances increased the yield of young olive trees. In 2015, KL-treated trees presented higher increases $(171 \%)$ in olive yield than in the SA-treated trees (65\%). In 2016, both products presented similar performance, averaging $78 \%$ and $73 \%$ for KL and SA treatments, respectively, which resulted in cumulative increases in the two harvests of $97 \%$ and $72 \%$. Both SA and KL treatments and harvest date influenced the MI of the fruits (Table 2). The tendency is constant in the three harvest dates, being the maturation stage slightly delayed by the application of SA and KL, namely in the 2016 season.

\subsection{Phenolic compounds and antioxidant capacity of olive fruits}

The content of phenolic compounds, namely TP, o-DP and Fl and antioxidant capacity responded differently to the harvest date during the 2015 season (Table 3). While the fruits from KL and SA-treated trees exhibited a decrease in both TP and Fl over the fruit ripening, the fruits from C plants exhibited increases of $8.8 \%$ and $23.7 \%$ in TP and Fl, respectively. By another side, the concentration of o-DP decreased in all treatments, but with higher depletion in KL fruits $(22.5 \%)$. The antioxidant capacity based on ABTS and DPPH assays followed a similar trend to TP and Fl (Table 3).

During the first harvest of 2015, both substances contributed to increase the levels of all phenolic compounds in fruits, with the order $\mathrm{C}<\mathrm{SA}<\mathrm{KL}$ for TP, $\mathrm{C} \leq \mathrm{SA} \leq \mathrm{KL}$ for o-DP and $\mathrm{C}<\mathrm{SA}$ and $\mathrm{KL}$ for $\mathrm{Fl}$ (Table 3). However, the higher decline in SA and KL fruits during ripening attenuate the differences in the second harvest, where only the concentrations of TP were still influenced by the treatments, being higher in KL fruits (Table 3). Relatively to 2015, in 2016 was noticed an increase in phenolics accumulation in all the analyzed treatments, highlighting the C fruits (Table 3). However, in 2016 harvest the response to the treatments was quite different from 2015. Both KL and SA treatments lead to a lower accumulation of TP and o-DP, while the Fl concentration was not affected (Table 3).

Table 2

Influence of control (C), salicylic acid (SA) and kaolin (KL) treatments, on maturation index of olives harvested in 2015 (November 9th (H1 2015) and 30th (H2 2015)) and in 2016 (December 9th (H1 2016)).

\begin{tabular}{lllll}
\hline & Date & C & SA & KL \\
\hline Maturation Index & H1 2015 & 3.12 & 3.04 & 2.95 \\
& H2 2015 & 3.45 & 3.39 & 3.22 \\
& H1 2016 & 3.90 & 3.36 & 3.26
\end{tabular}


Table 3

Influence of control (C), salicylic acid (SA) and kaolin (KL) treatments, on olive pulp chemical parameters: total phenols, ortho-diphenols and flavonoids content and antioxidant capacity (AC) based on DPPH, ABTS and FRAP assays. Olives were harvested in 2015 on November 9th (H1 2015) and 30th (H2 2015) and in 2016 on December 9th (H1 2016). Means $(n=9)$ followed by the same letter within the same harvest season are not significantly different at $P<0.05$.

\begin{tabular}{|c|c|c|c|c|c|}
\hline & Date & $\mathrm{C}$ & SA & KL & Sig. \\
\hline \multirow[t]{4}{*}{ Total Phenols (mg GAE $\mathrm{g}^{-1}$ ) } & H1 2015 & $27.6^{\mathrm{c}}$ & $32.7^{\mathrm{b}}$ & $36.3^{\mathbf{a}}$ & $* * * *$ \\
\hline & H2 2015 & $29.6^{\mathrm{b}}$ & $29.3^{b}$ & $31.7^{\mathbf{a}}$ & $* *$ \\
\hline & Sig. & & & & \\
\hline & H1 2016 & $41.2^{\mathrm{a}}$ & $38.4^{\mathrm{b}}$ & $39.0^{\mathbf{b}}$ & $* * * *$ \\
\hline \multirow[t]{4}{*}{ ortho-diphenols (mg GAE $\mathrm{g}^{-1}$ ) } & H1 2015 & $40.5^{b}$ & $43.1^{\mathbf{a b}}$ & $43.9^{a}$ & * \\
\hline & H2 2015 & 34.9 & 35.6 & 34.0 & n.s. \\
\hline & Sig. & & & & \\
\hline & H1 2016 & $40.8^{\mathrm{a}}$ & $38.0^{\mathrm{b}}$ & $38.5^{\mathbf{b}}$ & $* * * *$ \\
\hline \multirow[t]{4}{*}{ Flavonoids (mg CE $\mathrm{g}^{-1}$ ) } & H1 2015 & $26.9^{b}$ & $42.7^{\mathbf{a}}$ & $43.4^{\mathrm{a}}$ & $* * * *$ \\
\hline & H2 2015 & 33.3 & 32.1 & 32.8 & n.s. \\
\hline & Sig. & ***** & $* * * *$ & & \\
\hline & H1 2016 & 47.4 & 49.4 & 48.5 & n.s. \\
\hline \multirow[t]{3}{*}{ C- DPPH (mmol Trolox $\mathrm{kg}^{-1}$ ) } & H1 2015 & $81.7^{\mathbf{b}}$ & $123.8^{\mathrm{a}}$ & $131.7^{\mathrm{a}}$ & $* * *$ \\
\hline & $\begin{array}{l}\text { H2 } 2015 \\
\text { Sig. }\end{array}$ & 110.0 & 105.2 & 107.9 & n.s. \\
\hline & H1 2016 & $130.6^{\mathbf{a}}$ & $130.5^{\mathbf{a}}$ & $121.8^{\mathrm{b}}$ & $* *$ \\
\hline \multirow[t]{4}{*}{ AC - ABTS (mmol Trolox $\mathrm{kg}^{-1}$ ) } & H1 2015 & $141.6^{\mathrm{c}}$ & $176.2^{\mathrm{b}}$ & $207.7^{\mathrm{a}}$ & 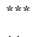 \\
\hline & H2 2015 & $174.5^{\mathrm{b}}$ & $170.6^{\mathrm{b}}$ & $190.1^{\mathrm{a}}$ & $* *$ \\
\hline & Sig. & & n.s. & & \\
\hline & H1 2016 & 319.0 & 311.2 & 320.3 & n.s. \\
\hline AC - FRAP (mmol Trolox $\left.\mathrm{kg}^{-1}\right)$ & H1 2016 & $214.3^{\mathbf{a}}$ & $190.2^{\mathrm{b}}$ & $185.1^{b}$ & **** \\
\hline
\end{tabular}

"-significant at $\mathrm{p}<0.05$; ${ }^{* *}$ - significant at $\mathrm{p}<0.01$; ${ }^{* * *}$ - significant at $\mathrm{p}<0.001$; n.s. - not significant at $\mathrm{p}>0.05$.

In general terms, the antioxidant capacity of fruits from $C$ trees was negatively affected in 2015, while it increases largely in 2016 (Table 3), following a similar trend of phenolic compounds. On the first harvest of 2015, the antioxidant capacity based on DPPH followed the order $\mathrm{C}<\mathrm{SA}$ and KL (Table 3). By using the ABTS assay, the order was similar, C $<$ SA $<$ KL (Table 3). On the second harvest of 2015, the statistical differences recorded for DPPH assay was annulated and by using the ABTS assay the KL still stood out (C and SA < KL, Table 3). In 2016, the antioxidant capacity response to the applied treatments was also influenced by the method in test, but with a different trend from the previous year (Table 3). While with the DPPH assay the order was $\mathrm{KL}<\mathrm{C}$ and SA, by using ABTS assay no differences were recorded (Table 3). The analysis of FRAP assay was also different with the order $\mathrm{KL}$ and SA < C (Table 3).

\subsection{Phenolic compounds and antioxidant capacity of olive oil}

The concentration of phenolic compounds in olive oil presented different patterns among years (Table 4). In 2015, the concentration of all quantified phenolics followed the order C $<$ KL $<$ SA (Table 4). On the other hand, the trend of phenolic compounds concentrations in 2016 was different, following the order SA and $\mathrm{KL}<\mathrm{C}$ for TP and Fl and $\mathrm{KL}<\mathrm{SA}<\mathrm{C}$ for o-DP (Table 4). Moreover, the increase in phenolics noticed in fruits, from 2015 to 2016 (Table 3), was more evident in the olive oil, as well the huge increase in the $C$ group (Table 4).

Following a similar trend of phenolic compounds concentrations, the olive oil analysis revealed a positive influence of KL and SA on the antioxidant capacity based on the antiradical activity in 2015, with the order $\mathrm{C}<\mathrm{SA}$ and $\mathrm{KL}$ for DPPH assay and $\mathrm{C}<\mathrm{KL}<\mathrm{SA}$ for ABTS assay (Table 4). Following the fruit tendency, in 2016 the $C$ group exhibited higher antioxidant capacity, with the order SA and $\mathrm{KL}<\mathrm{C}$ for DPPH and ABTS assays and KL $<$ SA $<$ C for FRAP assay (Table 4).
Table 4

Influence of control (C), salicylic acid (SA) and kaolin (KL) treatments, on olive oil chemical parameters: total phenols, ortho-diphenols and flavonoids content and antioxidant capacity (AC) based on DPPH, ABTS and FRAP assays.Means $(n=9)$ followed by the same letter within the same harvest season are not significantly different at $P<0.05$.

\begin{tabular}{|c|c|c|c|c|c|}
\hline & Date & $\mathrm{C}$ & SA & KL & Sig. \\
\hline \multirow[t]{2}{*}{ Total Phenols (mg GAE kg ${ }^{-1}$ ) } & 2015 & $84.0^{\mathrm{c}}$ & $123.0^{\mathbf{a}}$ & $113.1^{\mathrm{b}}$ & $* * * *$ \\
\hline & 2016 & $555.6^{\mathbf{a}}$ & $428.5^{b}$ & $412.1^{b}$ & $* * * * *$ \\
\hline \multirow[t]{2}{*}{ ortho-diphenols (mg GAE kg ${ }^{-1}$ ) } & 2015 & $63.5^{\mathrm{c}}$ & $72.0^{\mathrm{a}}$ & $66.6^{\mathrm{b}}$ & \\
\hline & 2016 & $195.1^{\mathbf{a}}$ & $152.4^{\mathrm{b}}$ & $136.8^{\mathrm{c}}$ & $* * * *$ \\
\hline \multirow[t]{2}{*}{ Flavonoids (mg CE kg ${ }^{-1}$ ) } & 2015 & $74.7^{\mathrm{c}}$ & $116.0^{\mathbf{a}}$ & $92.7^{\mathbf{b}}$ & * \\
\hline & 2016 & $557.3^{\mathrm{a}}$ & $401.9^{b}$ & $398.5^{\mathrm{b}}$ & * \\
\hline \multirow[t]{2}{*}{ AC - DPPH (mmol Trolox $\left.\mathrm{kg}^{-1}\right)$} & 2015 & $0.212^{\mathrm{b}}$ & $0.301^{\mathrm{a}}$ & $0.295^{\mathrm{a}}$ & * \\
\hline & 2016 & $1.23^{\mathrm{a}}$ & $0.910^{\mathbf{b}}$ & $0.827^{\mathrm{b}}$ & $* * * *$ \\
\hline \multirow[t]{2}{*}{ AC - ABTS (mmol Trolox $\mathrm{kg}^{-1}$ ) } & 2015 & $0.367^{\mathrm{c}}$ & $0.451^{\mathrm{a}}$ & $0.395^{\mathrm{b}}$ & *k*** \\
\hline & 2016 & $2.50^{\mathrm{a}}$ & $2.24^{\mathrm{b}}$ & $2.14^{\mathrm{b}}$ & \\
\hline AC - FRAP (mmol Trolox $\mathrm{kg}^{-1}$ ) & 2016 & $2.17^{\mathrm{a}}$ & $1.47^{\mathrm{b}}$ & $1.35^{\mathrm{c}}$ & $* * * *$ \\
\hline
\end{tabular}

$* * *$ significant at $\mathrm{p}<0.001$.

Table 5

Pearson correlation coefficients established between the antioxidant capacity and phenolics content.

\begin{tabular}{|c|c|c|c|c|c|c|}
\hline & $\mathrm{TP}(\mathrm{F})$ & $\mathrm{Fl}(\mathrm{F})$ & o-DP (F) & $\mathrm{TP}(\mathrm{O})$ & $\mathrm{Fl}(\mathrm{O})$ & o-DP (O) \\
\hline DPPH (F) & $0.788^{* * * * *}$ & $0.858^{\text {***** }}$ & 0.272 & & & \\
\hline ABTS (F) & $0.923^{* k * k x}$ & $0.863^{\text {***k }}$ & 0.109 & & & \\
\hline FRAP (F) & $0.923^{\text {k**kx }}$ & -0.246 & $0.947^{\text {k*k*k}}$ & & & \\
\hline DPPH (O) & & & & $0.994^{* * * *}$ & $0.994^{* * * *}$ & $0.992^{* * * *}$ \\
\hline ABTS (O) & & & & $0.988^{* * * *}$ & $0.982^{* * * * *}$ & $0.968^{\text {***ke }}$ \\
\hline FRAP (O) & & & & $0.969^{* * * * k}$ & $0.973^{\text {ktkek }}$ & $0.970^{\text {***k }}$ \\
\hline
\end{tabular}

TP $(\mathrm{F})$ and TP $(\mathrm{O})=$ total phenols content in fruits and oil, respectively; Fl (F) and $\mathrm{Fl}(\mathrm{O})=$ flavonoids content in fruits and oil, respectively; o-DP $(\mathrm{F})$ and oDP (O) = ortho-diphenols content in fruits and oil, respectively; DPPH (F) and DPPH (O) = antioxidant capacity based on DPPH assay in fruits and oil, respectively; ABTS (F) and ABTS (O) = antioxidant capacity based on ABTS assay in fruits and oil, respectively; FRAP (F) and FRAP $(\mathrm{O})=$ antioxidant capacity based on FRAP assay in fruits and oil, respectively. ${ }^{* * * *}$ - significant at $\mathrm{p}<0.001$.

\subsection{Correlation analysis}

As presented in Table 5, in general terms the antioxidant capacity was significantly positive correlated with the phenolic concentrations, showing that phenols have a high association with the antioxidant capacity of olives and olive oil. In fruits, TP showed a significant positive correlation with all the antioxidant capacity methods tested, being this relationship strong for DPPH and very strong for both ABTS and FRAP methods, while Fl showed a very strong correlation with DPPH and ABTS methods and o-DP with FRAP method. In opposite to the fruits, in olive oil the correlation between the phenolic compounds and the antioxidant capacity methods was persistently very strong (Table 5).

\subsection{Olive oil quality parameters}

The oil quality indices FA, PV, $\mathrm{K}_{232}$ and $\Delta \mathrm{K}$ were not affected by the applied treatments, whereas the $\mathrm{K}_{270}$ coefficient was reduced by both SA and KL application (Table 6).

\section{Discussion}

\subsection{Yield and ripening degree of fruits}

The increase in yield promoted by KL and SA agrees with previous studies in different plant species (Abd El-Razek et al., 2013; Chamchaiyaporn et al., 2013; Correia et al., 2014; El-Shazly et al., 2013; Glenn et al., 2003; Jamali et al., 2011; Kazemi, 2013; Khalil et al., 
Table 6

Influence of control (C), salicylic acid (SA) and kaolin (KL) treatments on olive oil quality indices (FA -Free Acidity; PV - Peroxide Value; $\mathrm{K}_{232}$ - specific extinction at wavelength $232 ; \mathrm{K}_{270}$ - specific extinction at wavelength $270 ; \Delta \mathrm{K}-$ Variation of the specific extinction). Means $(n=3)$ followed by the same letter are not significantly different at $\mathrm{P}<0.05$.

\begin{tabular}{lllll}
\hline Oil quality indices in 2016 & $\mathrm{C}$ & SA & KL & Sig. \\
\hline FA (\% oleic acid) & 0.388 & 0.390 & 0.392 & n.s. \\
$\mathrm{PV} \mathrm{(mgEq} \mathrm{O}_{2} \mathrm{~kg}^{-1}$ oil) & 2.73 & 2.70 & 2.69 & n.s. \\
$\mathrm{K}_{232}$ & 2.03 & 1.96 & 1.96 & n.s. \\
$\mathrm{K}_{270}$ & $0.165^{\mathrm{a}}$ & $0.151^{\mathrm{b}}$ & $0.142^{\mathrm{b}}$ & *.* \\
$\Delta \mathrm{K}$ & 0.0025 & 0.0032 & 0.0027 & n.s. \\
\hline
\end{tabular}

$* *$ significant at $\mathrm{p}<0.01 ;$ n.s. - not significant at $\mathrm{p}>0.05$.

2012; Saour and Makee, 2003). Moreover, it is also important to notice that albeit the significant differences in yield in the 1st year, namely in KL-treated plants, the differences in olive yield in the 2nd year were notorious, since this species suffers from the peculiar phenomenon of alternate bearing, particularly under rainfed conditions, as in the present study. In addition, the severe summer stress verified in 2016 also contributed to limit potential crop yield in that year. Meanwhile, the delay of maturation stage by the application of SA and KL was closely associated with the higher fruit yield. Similar relationship between crop load and fruit ripening was previously verified (Barone et al., 1994).

\subsection{Influence of the harvest time on the phenolic compounds content and antioxidant capacity of olive fruits}

An overall decrease in phenolic compounds concentrations and in antioxidant capacity of olive fruits during ripening is a common described phenomenon (Barros et al., 2013; Brahmi et al., 2013; Damak et al., 2008; Machado et al., 2013; Sousa et al., 2014a, 2015; Sousa et al., 2014b; Talhaoui et al., 2015), due to chemical and enzymatic reactions occurring during the ripening process (Ye et al., 2014). In the present study, this decrease was highly notorious in o-DP contents (Table 3). By other side, the increase in TP (8.8\%) and Fl (23.7\%) concentrations noticed in $\mathrm{C}$ plants over the fruit ripening (Table 3) may be justified by the appearance of other classes of phenolic compounds. Oleuropein, an ortho-diphenolic compound, is the most abundant phenolic during the green stage, but decreases sharply during the maturation, while by other side the black maturation phase is characterized by the appearance of other compounds, such as flavonoids, specially anthocyanins (Damak et al., 2008; Jemai et al., 2009; Machado et al., 2013; Sousa et al., 2014a; Talhaoui et al., 2015). This assumption is consistent with the discoveries of Barros et al. (2013) since they found an overall increase of flavonoids concentration from green to black stages in different olive cultivars, including "Cobrançosa".

\subsection{Accumulation of phenolic compounds on fruits and olive oil in response to the applied treatments}

The different trend in phenolic compounds accumulation recorded in 2015 and 2016 (Tables 3 and 4) may be justified by the distinctive environmental conditions that include frost events before harvest in 2015 and severe summer stress in 2016. Stress conditions influence the metabolism of phenolic compounds in fruits, mainly in two ways, which are not mutually exclusive and that may even interact. First, due to the reduction in net photosynthesis that may result in a decrease in carbohydrate supply to the fruits, the major source of precursors for the biosynthesis of these phytochemicals; second, the stress conditions may exacerbate the oxidative stress, promoting the biosynthesis of this group of antioxidant compounds (Ripoll et al., 2014; Wang and Frei, 2011). To notice, phenolic compounds accumulate more, both in fruits and olive oil, in 2016 than in 2015 harvest (Tables 3 and 4). As can be seen in Fig. 1, during the fruit development, the accumulated precipitation was much higher in 2015 than in 2016, mainly in October $(123.6 \mathrm{~mm})$, close to the harvest time. Moreover, 2015 had a less hot summer. These data justify the higher accumulation of phenolic compounds in 2016, in agreement with other studies, which reported that stressful conditions increase the accumulation of phenolic compounds in olive fruits (Gómez-Rico et al., 2006; Machado et al., 2013). On the other side, in 2015 the plants were exposed to frost events before the harvest, coinciding one of those events with the second harvest of 2015. With temperatures below $0{ }^{\circ} \mathrm{C}$ occurs the freezing of extracellular water, and the thermodynamic equilibrium is achieved either by cellular dehydration and continued extracellular ice formation, or by intracellular ice formation. These effects seriously damage cell membranes, leading to cell death and the oxidative degradation of cell contents, as phenolic compounds, due to the contact between enzymes and their respective substrates (Morelló et al., 2003). Indeed, it is known that frost events can damage olive fruits and consequently the quality of the extracted olive oil, including the decrease in pigments and phenolic compounds concentrations (Houliston et al., 2007; Morelló et al., 2003; Morelló et al., 2006). As the early frosts are very common in this region, it is recommended to anticipate the harvest time, usually adopted by the local farmers. Interestingly, Morelló et al. (2006) reported that in crop seasons following the frost events, the concentration of phenolic compounds increases significantly, associating this response to the fact that the previously frost damaged olive trees were more sensitive to water deficit during summer.

Regarding the differences among treatments, it is important to refer that KL and SA ameliorate the olive photosynthetic rate during the fruit development (unpublished results). In the first year, this response not only contributed to higher crop yield, but also to a slight higher accumulation of phenolic compounds in the fruits (Table 3). Moreover, the plants sprayed with SA and KL were physiologically less damaged with the frost events (unpublished results). However, as in 2016 the plants face severest stress conditions during the summer period (Fig. 1), the control plants, that were in worst physiological conditions (unpublished results), increase the investment in these phytochemicals in order to increase the free radical scavenging activity. Thus, these data demonstrate the effectiveness of the applied substances in reducing the degree of frost damage and in mitigating the extreme adverse conditions that were felt in 2016, namely in summer.

The present study showed that a very low percentage of total phenolic compounds were transferred from olive pulp to oil, being higher in 2016 in a closely association with the prevailing climatic conditions reported previously. Moreover, phenolic compounds changed qualitatively and quantitatively during the transfer, as in the study of Ye et al. (2014), resulting in quite different phenolic composition of olive oil compared to that of olive flesh. To explain the different trend in the transference of phenolic compounds to oil between years and among the applied treatments (Tables 3 and 4) different hypothesis were raised: variations in pulp moisture $(69.8 \%$ to $71.1 \%$ in 2015 and $60.5 \%$ to $61.4 \%$ in 2016), since higher moisture affects negatively the transfer of phenolics to the oil; changes in enzymes activities during the pressing and malaxation steps; and/ or changes in the transference of specific phenolics presented in olive stones, lignans, after whole olive fruits crushing and malaxation (Oliveras López et al., 2008; Talhaoui et al., 2016). Yet, the initial characteristics of the olive fruits, such as phenolic composition, is probably the most important variable involved in the quality of the final olive oil (Fregapane and Salvador, 2013). As stated previously, the information about the influence of both SA and KL in phenolic composition of fruits is scarce and sometimes not consensual. Indeed, a global analysis of the literature previously cited and our results reveal that other factors, such as genotypes or environmental conditions, may determine the influence of these mitigating agents in fruits quality. 


\subsection{Antioxidant capacity of fruits and olive oil}

The global antioxidant capacity of an extract reflects both the "antiradical" and the "antioxidant" activity, that not necessarily coincide (Tirzitis and Bartosz, 2010). The antiradical activity characterizes the ability of compounds to react with free radicals (e. g. ABTS and DPPH assays) and antioxidant activity represents the ability to inhibit the process of oxidation (e. g. FRAP assay) (Moharram and Youssef, 2014; Tirzitis and Bartosz, 2010). Therefore, to better understand the global antioxidant capacity of olives and olive oil, methanolic extracts were evaluated by three different assays to cover different mechanisms of the antioxidant defense system: DPPH and $\mathrm{ABTS}^{+}{ }^{+}$radicals scavenging activity and FRAP. Indeed, according to the method tested the antioxidant capacity presented a different behavior (Tables 3 and 4), highlighting the importance of testing different methods. It is well established the influence of phenolic compounds on the antioxidant capacity of olive fruits and oil (Brahmi et al., 2013; Gouvinhas et al., 2014; Jemai et al., 2009; Sousa et al., 2014a; Tripoli et al., 2005). Nevertheless, other compounds with antioxidant capacity are known to be present in these products (Jemai et al., 2009; Sousa et al., 2014a), which may contribute to some different trends detected between phenols and the antioxidant capacity (Tables 3 and 4).

\subsection{Correlation analysis}

The correlation analysis suggest that the nature of phenolic compounds determine its ability to reduce the $\mathrm{ABTS}^{*}+$ and DPPH radicals and the ferric iron. Moreover, those data also suggest that in olive oil the phenolic compounds are the most responsible for the antioxidant capacity and that in fruits, the presence of other constituents in the extracts could also have an important contribution to the antioxidant capacity. For instance, Jemai et al. (2009) reported that the presence of sugar alcohols, as mannitol, enhances the ability of the extract to act as an antioxidant because it is known to be a quencher of ROS and scavenger of hydroxyl radicals. The correlation between the antioxidant capacity and the level of phenolic compounds has been largely described, but, in fact, it is very dependent on its structure, specially the number and the position of hydroxyl substituents in the aromatic ring (Boskou et al., 2006; Bouaziz et al., 2005; Gouvinhas et al., 2014; RiceEvans et al., 1996; Silva et al., 2006; Sousa et al., 2014a).

\subsection{Influence of the applied treatments on oil quality parameters}

Since the harvesting, transportation, storage and extraction process were equal among the treatments, the similar values of olive oil FA (Table 6) reflect the same quality of the olives (Khaleghi et al., 2015). As far as we know, no study access previously the influence of SA application in olive oil quality indices. Regarding KL application, our results corroborate the study of Saour and Makee (2003) whereas Khaleghi et al. (2015) reported a reduction of FA with the application of kaolin.

The higher PV means the greater degradation of the oil due to oxidation (Khaleghi et al., 2015). The absence of KL effects in this index contradicts the results of Saour and Makee (2003) and Khaleghi et al. (2015), that showed a lower PV in olive oil from KL-treated trees.

The lower $\mathrm{K}_{270}$ absorption coefficient in oils from KL and SA treatments (Table 6) indicates a fewer formation of secondary products of oxidation in the oils from sprayed trees (Limón et al., 2015). A reduction in both $\mathrm{K}_{232}$ and $\mathrm{K}_{270}$ absorption coefficients with KL application was already described in the literature (Khaleghi et al., 2015; Saour and Makee, 2003). According to the European Community EEC/2568/ 91 (Regulation, 1991) the evaluated indices of all the analyzed olive oils fall within the ranges established for "extra virgin olive oil" category. FA $(0.388-0.392 \%)$ are below the limit of $0.8 \%$, PV (2.693-2.733 mEq $\mathrm{O}_{2} \mathrm{Kg}^{-1}$ ) are below the limit of $20 \mathrm{mEq} \mathrm{O}_{2} \mathrm{Kg}^{-1}$ and the UV spectrophotometric coefficients are also below the stablished limits, 2.5 for $\mathrm{K}_{232}(1.957-2.026), 0.22$ for $\mathrm{K}_{270}(0.142-0.165)$ and 0.01 for $\Delta \mathrm{K}$ (0.0025-0.0032).

\section{Conclusions}

This study provided evidences that yield, phenolics compounds and antioxidant capacity of olive fruits and olive oil are modulated by the applied mitigating agents. Both SA and KL lead to an increase in olive yield. However, it is hard to conclude their influence on the phenolic composition and antioxidant capacity, since the climatic conditions determine different responses by the plants. The lower concentration of phenolic compounds under higher maturation index was accelerated by $\mathrm{KL}$ and SA. In general, both stress mitigating agents increased the concentration of phenolic compounds and antioxidant capacity in both fruits and oil on the first year, but decreased their levels on the second year, in a closely association with the prevailing climatic conditions. The quality indices of olive oils set by the European Community EEC/ 2568/91(Regulation, 1991) were not negatively affected by KL and SA. On the contrary, oils from KL and SA treatments presented lower formation of secondary products oxidation. Both KL and SA compounds were effective in reducing the degree of frost damage and in mitigating the adverse summer conditions, typical of Mediterranean olive growing areas.

\section{Acknowledgements}

Doctoral fellowship under the Doctoral Program "Agricultural Production Chains - from fork to farm" (PD/00122/2012) provided by the FCT-Portuguese Foundation for Science and Technology to C. Brito (PD/BD/ 52543/2014). Institution CITAB, for its financial support through the European Investment Funds by FEDER/COMPETE/POCIOperational Competitiveness and Internationalization Program, under Project POCI-01-0145-FEDER-006958 and National Funds by FCT Portuguese Foundation for Science and Technology, under the project UID/AGR/04033/2013. INTERACT project - "Integrative Research in Environment, Agro-Chains and Technology", no. NORTE-01-0145FEDER-000017, in its lines of research entitled ISAC, co-financied by the European Regional Development Fund (ERDF) through NORTE 2020 (North Regional Operational Program 2014/2020).

\section{References}

Moharram, A.H., Youssef, M., 2014. Methods for determining the antioxidant activity: a review. Alex. J. Food Sci. Technol. 11, 31-42.

Abd El-Razek, E.E.-D., Hassan, H., Gamal El-Din, K., 2013. Effect of foliar application with salicylic acid, benzyladenine and gibberellic acid on flowering, yield and fruit quality of olive trees (Olea europaea L.). Middle East J. Sci. Res. 14, 1401-1406.

Barone, E., Gullo, G., Zappia, R., Inglese, P., 1994. Effect of crop load on fruit ripening and olive oil (Olea europea L.) quality. J. Hortic. Sci. 69, 67-73. http://dx.doi.org/10, 1080/14620316.1994.11515250.

Barros, A.I., Freire, I., Gonçalves, B., Bacelar, E., Gomes, S., Lopes, J., Guedes-Pinto, H., Martins-Lopes, P., 2013. Evaluation of chemical and phenotypic changes in Blanqueta, Cobrançosa, and Galega during olive fruits ripening. CyTA J. Food 11, 136-141. http://dx.doi.org/10.1080/19476337.2012.705329.

Barros, A.I.R.N.A., Nunes, F.M., Gonçalves, B., Bennett, R.N., Silva, A.P., 2011. Effect of cooking on total vitamin $\mathrm{C}$ contents and antioxidant activity of sweet chestnuts (Castanea sativa Mill.). Food Chem. 128, 165-172. http://dx.doi.org/10.1016/j. foodchem.2011.03.013.

Bolanos de la Torre, A.A.S., Henderson, T., Nigam, P.S., Owusu-Apenten, R.K., 2015. A universally calibrated microplate ferric reducing antioxidant power (FRAP) assay for foods and applications to Manuka honey. Food Chem. 174, 119-123. http://dx.doi. org/10.1016/j.foodchem.2014.11.009.

Boskou, G., Salta, F.N., Chrysostomou, S., Mylona, A., Chiou, A., Andrikopoulos, N.K. 2006. Antioxidant capacity and phenolic profile of table olives from the Greek market. Food Chem. 94, 558-564. http://dx.doi.org/10.1016/j.foodchem.2004.12. 005.

Bouaziz, M., Grayer, R.J., Simmonds, M.S., Damak, M., Sayadi, S., 2005. Identification and antioxidant potential of flavonoids and low molecular weight phenols in olive cultivar chemlali growing in Tunisia. J. Agric. Food Chem. 53, 236-241. http://dx. doi.org/10.1021/jf048859d.

Brahmi, F., Mechri, B., Dhibi, M., Hammami, M., 2013. Variations in phenolic compounds and antiradical scavenging activity of Olea europaea leaves and fruits extracts collected in two different seasons. Ind. Crops Prod. 49, 256-264. http://dx.doi.org/10. 
1016/j.indcrop.2013.04.042

Chamchaiyaporn, T., Jutamanee, K., Kasemsap, P., Vaithanomsat, P., Henpitak, C., 2013. Effects of kaolin clay coating on mango leaf gas exchange, fruit yield and quality. Kasetsart J. (Nat. Sci.) 47, 479-491.

Charoenprasert, S., Mitchell, A., 2012. Factors influencing phenolic compounds in table olives (Olea europaea). J. Agric. Food Chem. 60, 7081-7095. http://dx.doi.org/10. 1021/jf3017699.

Correia, C., Dinis, L.-T., Pinheiro, R., Fraga, H., Ferreira, H., Gonçalves, I., Costa, J., Fernandes de Oliveira, A., Malheiro, A., Moutinho Pereira, J., 2014. Climate change and adaptation strategies for viticulture. J. Int. Sci. Publ. 2, 424-429. http://dx.doi. org/10.13140/2.1.2377.0242.

Damak, N., Bouaziz, M., Ayadi, M., Sayadi, S., Damak, M., 2008. Effect of the maturation process on the phenolic fractions, fatty acids, and antioxidant activity of the Chétoui olive fruit cultivar. J. Agric. Food Chem. 56, 1560-1566. http://dx.doi.org/10.1021/ jf072273k.

Dinis, L.T., Bernardo, S., Conde, A., Pimentel, D., Ferreira, H., Félix, L., Gerós, H., Correia, C.M., Moutinho-Pereira, J., 2016. Kaolin exogenous application boosts antioxidant capacity and phenolic content in berries and leaves of grapevine under summer stress. J. Plant Physiol. 191, 45-53. http://dx.doi.org/10.1016/j.jplph.2015.12.005.

Domínguez-Perles, R., Teixeira, A.I., Rosa, E., Barros, A.I., 2014. Assessment of (poly) phenols in grape (Vitis vinifera L.) stems by using food/pharma industry compatible solvents and response surface methodology. Food Chem. 164, 339-346. http://dx. doi.org/10.1016/j.foodchem.2014.05.020.

El-Shazly, S.M., Eisa, A.M., Moảtamed, A.M.H., Kotb, H.R.M., 2013. Effect of some agrochemicals preharvest foliar application on yield and fruit quality of "Swelling" peach trees. Alex. J. Agric. Res. 58, 219-229.

Fregapane, G., Salvador, M.D., 2013. Production of superior quality extra virgin olive oil modulating the content and profile of its minor components. Food. Res. Int. 54, 1907-1914. http://dx.doi.org/10.1016/j.foodres.2013.04.022.

Ghanbari, R., Anwar, F., Alkharfy, K.M., Gilani, A.-H., Saari, N., 2012. Valuable nutrients and functional bioactives in different parts of olive (Olea europaea L.)-A review. Int. J. Mol. Sci. 13, 3291-3340. http://dx.doi.org/10.3390/ijms13033291.

Glenn, D.M., Erez, A., Puterka, G.J., Gundrum, P., 2003. Particle films affect carbon assimilation and yield in `Empire’ apple. J. Am. Soc. Hortic. Sci. 128, 356-362.

Glenn, D.M., Puterka, G.J., 2004. Particle films: a new technology for agriculture. In: Janick, J. (Ed.), Horticultural Reviews. John Wiley \& Sons, Inc, Oxford, UK. http:// dx.doi.org/10.1002/9780470650882.ch1. pp. 1-44.

Gómez-Rico, A., Salvador, M.D., La Greca, M., Fregapane, G., 2006. Phenolic and volatile compounds of extra virgin olive oil (Olea europaea L. Cv. Cornicabra) with regard to fruit ripening and irrigation management. J. Agric. Food Chem. 54, 7130-7136. http://dx.doi.org/10.1021/jf060798r.

Gouvinhas, I., Machado, J., Gomes, S., Lopes, J., Martins-Lopes, P., Barros, A.I.R.N.A., 2014. Phenolic composition and antioxidant activity of monovarietal and commercial Portuguese olive oils. J. Am. Oil Chem. Soc. 91, 1197-1203. http://dx.doi.org/10. 1007/s11746-014-2462-x.

Hermoso, M., Uceda, M., Garcia, A., Morales, B., Frias, M.L., Férnandez, A., 1991. Elaboración de aceite de calidad. Junta de Andalucía. Consejería de Agricultura y Pesca, Sevilla, Spain.

Houba, V.J.G., van der Lee, J.J., Novozamsky, I., 1997. Soil Analysis Procedures, Other Procedures. Landbouwuniversiteit, Wagningen, NL.

Houliston, A., Vanhanen, L., Savage, G., 2007. Frost protection of olives using glycine betaine. Sci. Thecnol. 108, 31-40.

IPCC, 2013. Climate change 2013: the physical science basis. In: Stocker, T.F., Qin, D., Plattner, G.-K., Tignor, M., Allen, S.K., Boschung, J., Nauels, A., Xia, Y., Bex, V., Midgley, P.M. (Eds.), Contribution of Working Group I to the Fifth Assessment Report of the Intergovernmental Panel on Climate Change. Cambridge University Press, New York.

IPMA, 2017. Instituto Português do Mar e da Atmosfera. (Acessed 13 November 2017). http://www.ipma.pt/pt/oclima/normais.clima/.

Jamali, B., Eshghi, S., Tafazoli, E., 2011. Vegetative and reproductive growth of strawberry plants cv. 'Pajaro' affected by salicylic acid and nickel. J. Agr. Sci. Technol. 13, 895-904.

Jemai, H., Bouaziz, M., Sayadi, S., 2009. Phenolic composition, sugar contents and antioxidant activity of Tunisian sweet olive cultivar with regard to fruit ripening. J. Agric. Food Chem. 57, 2961-2968. http://dx.doi.org/10.1021/jf8034176.

Kazemi, M., 2013. Foliar application of salicylic acid and calcium on yield, yield component and chemical properties of strawberry. Bull. Environ. Pharmacol. Life Sci. 2, $19-23$.

Keren, R., 1996. Boron. In: Sparks, D.L., Page, A.L., Helmke, P.A., Loeppert, R.H. (Eds.), Methods of Soil Analysis Part 3-Chemical Methods. SSSA, ASA, Madison, WI, pp. 603-626. http://dx.doi.org/10.2136/sssabookser5.3.frontmatter. SSSA Book Ser. 5.3 .

Khaleghi, E., Arzani, K., Moallemi, N., Barzegar, M., 2015. The efficacy of kaolin particle film on oil quality indices of olive trees (Olea europaea L.) cv 'Zard' grown under warm and semi-arid region of Iran. Food Chem. 166, 35-41. http://dx.doi.org/10 1016/j.foodchem.2014.06.006.

Khalil, F., Qureshi, K.M., Khan, A., Fakhar ul, H., Bibi, N., 2012. Effect of girdling and plant growth regulators on productivity in olive (Olea europaea). Pak. J. Agric. Res. $25,30-38$.

Khan, M.I.R., Fatma, M., Per, T.S., Anjum, N.A., Khan, N.A., 2015. Salicylic acid-induced abiotic stress tolerance and underlying mechanisms in plants. Front. Plant Sci. 6. http://dx.doi.org/10.3389/fpls.2015.00462.

Limón, P., Malheiro, R., Casal, S., Acién-Fernández, F.G., Fernández-Sevilla, J.M., Rodrigues, N., Cruz, R., Bermejo, R., Pereira, J.A., 2015. Improvement of stability and carotenoids fraction of virgin olive oils by addition of microalgae Scenedesmus almeriensis extracts. Food Chem. 175, 203-211. http://dx.doi.org/10.1016/j. foodchem.2014.10.150

Machado, M., Felizardo, C., Fernandes-Silva, A.A., Nunes, F.M., Barros, A., 2013. Polyphenolic compounds, antioxidant activity and l-phenylalanine ammonia-lyase activity during ripening of olive cv. "Cobrançosa" under different irrigation regimes. Food. Res. Int. 51, 412-421. http://dx.doi.org/10.1016/j.foodres.2012.12.056.

Mateos, R., Espartero, J.L., Trujillo, M., Ríos, J.J., León-Camacho, M., Alcudia, F., Cert, A., 2001. Determination of phenols, flavones, and lignans in virgin olive oils by solidphase extraction and high-performance liquid chromatography with diode array ultraviolet detection. J. Agric. Food Chem. 49, 2185-2192. http://dx.doi.org/10.1021/ jf0013205.

Morelló, J.-R., Motilva, M.-J., Ramo, T., Romero, M.-P., 2003. Effect of freeze injuries in olive fruit on virgin olive oil composition. Food Chem. 81, 547-553. http://dx.doi. org/10.1016/S0308-8146(02)00488-0.

Morelló, J.R., Romero, M.P., Motilva, M.J., 2006. Influence of seasonal conditions on the composition and quality parameters of monovarietal virgin olive oils. J. Am. Oil Chem. Soc. 83, 683-690. http://dx.doi.org/10.1007/s11746-006-5024-z.

Oliveras López, M.J., Innocenti, M., Ieri, F., Giaccherini, C., Romani, A., Mulinacci, N., 2008. HPLC/DAD/ESI/MS detection of lignans from Spanish and Italian Olea europaea L. fruits. J. Food Compost. Anal. 21, 62-70. http://dx.doi.org/10.1016/j.jfca. 2007.04.012.

Ozgen, M., Reese, R.N., Tulio, A.Z., Scheerens, J.C., Miller, A.R., 2006. Modified 2,2Azino-bis-3-ethylbenzothiazoline-6-sulfonic acid (ABTS) method to measure antioxidant capacity of selected small fruits and comparison to Ferric Reducing Antioxidant Power (FRAP) and 2,2'-Diphenyl-1-picrylhydrazyl (DPPH) methods. J. Agric. Food Chem. 54, 1151-1157. http://dx.doi.org/10.1021/jf051960d.

Regulation, C, 1991. (EEC) No. 2568/91: on the characteristics of olive oil and olivepomace oil and on the relevant methods of analysis. Off. J. Eur. Union. L248, 1-82.

Rice-Evans, C.A., Miller, N.J., Paganga, G., 1996. Structure-antioxidant activity relationships of flavonoids and phenolic acids. Free Radic. Biol. Med. 20, 933-956. http://dx.doi.org/10.1016/0891-5849(95)02227-9.

Ripoll, J., Urban, L., Staudt, M., Lopez-Lauri, F., Bidel, L.P., Bertin, N., 2014. Water shortage and quality of fleshy fruits-making the most of the unavoidable. J. Exp. Bot. 65, 4097-4117. http://dx.doi.org/10.1093/jxb/eru197.

Saour, G., Makee, H., 2003. Effects of kaolin particle film on olive fruit yield, oil content and quality. Adv. Hortic. Sci. 17, 204-206.

Servili, M., Esposto, S., Fabiani, R., Urbani, S., Taticchi, A., Mariucci, F., Selvaggini, R., Montedoro, G.F., 2009. Phenolic compounds in olive oil: antioxidant, health and organoleptic activities according to their chemical structure. Inflammopharmacology 17, 76-84. http://dx.doi.org/10.1007/s10787-008-8014-y.

Silva, S., Gomes, L., Leitão, F., Coelho, A.V., Boas, L.V., 2006. Phenolic compounds and antioxidant activity of Olea europaea L. fruits and leaves. Food Sci. Technol. Int. 12, 385-395. http://dx.doi.org/10.1177/1082013206070166.

Soufi, O., Romero, C., Louaileche, H., 2014. Ortho-diphenol profile and antioxidant activity of Algerian black olive cultivars: effect of dry salting process. Food Chem. 157, 504-510. http://dx.doi.org/10.1016/j.foodchem.2014.02.075.

Sousa, A., Malheiro, R., Casal, S., Bento, A., Pereira, J.A., 2014a. Antioxidant activity and phenolic composition of $\mathrm{Cv}$. Cobrançosa olives affected through the maturation process. J. Funct. Foods 11, 20-29. http://dx.doi.org/10.1016/j.jff.2014.08.024.

Sousa, A., Malheiro, R., Casal, S., Bento, A., Pereira, J.A., 2015. Optimal harvesting period for cvs. Madural and Verdeal Transmontana, based on antioxidant potential and phenolic composition of olives. LWT-Food Sci. Technol. 62, 1120-1126. http://dx. doi.org/10.1016/j.lwt.2015.01.046.

Sousa, C., Gouvinhas, I., Barreira, D., Carvalho, M.T., Vilela, A., Lopes, J., Martins-Lopes, P., Barros, A.I., 2014b. 'Cobrançosa' olive oil and drupe: chemical composition at two ripening stages. J. Am. Oil. Chem. Soc. 91, 599-611. http://dx.doi.org/10.1007/ s11746-013-2406-x.

Talhaoui, N., Gómez-Caravaca, A.M., León, L., De la Rosa, R., Fernández-Gutiérrez, A., Segura-Carretero, A., 2015. Pattern of variation of fruit traits and phenol content in olive fruits from six different cultivars. J. Agric. Food Chem. 63, 10466-10476. http://dx.doi.org/10.1021/acs.jafc.5b04315.

Talhaoui, N., Gómez-Caravaca, A.M., León, L., De la Rosa, R., Fernández-Gutiérrez, A., Segura-Carretero, A., 2016. From olive fruits to olive oil: phenolic compound transfer in six different olive cultivars grown under the Same agronomical conditions. Int. J. Mol. Sci. 17, 337. http://dx.doi.org/10.3390/ijms17030337.

Tirzitis, G., Bartosz, G., 2010. Determination of antiradical and antioxidant activity: basic principles and new insights. Acta Biochim. Pol. 57, 139-142.

Tripoli, E., Giammanco, M., Tabacchi, G., Di Majo, D., Giammanco, S., La Guardia, M., 2005. The phenolic compounds of olive oil: structure, biological activity and beneficial effects on human health. Nutr. Res. Ver. 18, 98-112. http://dx.doi.org/10. 1079/NRR200495.

Van Reeuwijk, L.P., 2002. Procedures for soil analysis. Technical Paper 9. ISRIC, FAO, Wagningen, NL.

Vinha, A.F., Ferreres, F., Silva, B.M., Valentão, P.C., Gonçalves, A., Pereira, J.A., Oliveira, M.B., Seabra, R.M., Andrade, P.B., 2005. Phenolic profiles of Portuguese olive fruits (Olea europaea L.): Influences of cultivar and geographical origin. Food Chem. 89, 561-568. http://dx.doi.org/10.1016/j.foodchem.2004.03.012.

Wang, Y., Frei, M., 2011. Stressed food - the impact of abiotic environmental stresses on crop quality. Agric. Ecosyst. Environ. 141, 271-286. http://dx.doi.org/10.1016/j. agee.2011.03.017.

Ye, J.H., Wijesundera, C., Shi, M., 2014. Effects of agronomic and oil processing conditions on natural antioxidative phenolics in olive (Oleaeuropaea L.). Austin. J. Nutr. Food Sci. 2, 1-8.

Zhishen, J., Mengcheng, T., Jianming, W., 1999. The determination of flavonoid contents in mulberry and their scavenging effects on superoxide radicals. Food Chem. 64, 555-559. http://dx.doi.org/10.1016/S0308-8146(98)00102-2. 